\title{
REFLECTION OF SOME LIFE STYLE FACTORS ON ARTERIAL BLOOD PRESSURE
}

\author{
Ragb, M. H. ${ }^{(1)}$; Boghdady, Y. ${ }^{(2)}$; El-Hamamosy, Manal, H. ${ }^{(3)}$ \\ and Mohamed,Wafaa, $M$. \\ 1) Community and Environmental Medicine department Institute of \\ Environmental Research Studies, Ain Shams University. 2) Cardiology \\ department Faculty of Medicine, Cairo University. 3) Clinical Pharmacy \\ departement Faculty of Pharmacy, Ain Shams University.
}

\begin{abstract}
High blood pressure remains a major cause of cardiovascular morbidity and mortality worldwide; risk factors for developing hypertension divided to non modifiable (age, gender, inherited risks), and modifiable (food therapy, losing weight, getting regular exercise, quitting smoking as well managing stress). Studying lifestyle pattern of population is required for controlling and prevention of hypertension complications. The current study was carried out to detect the effect of some life style factors on blood pressure.

The subject of the study are male middle aged (20-40) years and classified according to blood pressure measurement into: group 1 normotensive subject $(n=50), 2$-hypertensive subject $(n=50)$. An interviewing questionnaire of lifestyle pattern was developed and utilized by the investigator. A descriptive correlation research design was utilized to achieve the aim of the present study.

There was a significant relation between HTN and lifestyle pattern regarding (body weight, physical activity, stress, and smoking.The current study concluded that following unhealthy lifestyle pattern can lead to HTN. The study recommended applying modified lifestyle pattern can improve blood pressure and decrease the risk of associated health complication.
\end{abstract}

Keywords: blood pressure, hypertension, life style, obesity, physical in activity, smoking and stress. 
J. Environ. Sci.

Institute of Environmental Studies and Research - Ain Shams University

\section{INTRODUCTION}

Blood pressure (BP) is the pressure exerted by circulating blood upon the walls of blood vessels, and is one of the principal vital signs. When used without further specification, "blood pressure" usually refers to the arterial pressure of the systemic circulation.

\section{Classification of blood pressure for adults (JNC7)}

\begin{tabular}{|c|c|c|}
\hline Category & $\begin{array}{c}\text { Systolic, } \\
\mathbf{m m ~ H g}\end{array}$ & $\begin{array}{c}\text { diastolic, } \\
\mathbf{m m ~ H g}\end{array}$ \\
\hline Normal & $90-199$ & $60-79$ \\
\hline High normal (Prehypertension) & $120-139$ & $80-89$ \\
\hline Stage 1 hypertension & $140-159$ & $90-99$ \\
\hline Stage 2 hypertension & $160-179$ & $100-109$ \\
\hline Stage 3 hypertension (Hypertensive emergency) & $\geq 180$ & $\geq 110$ \\
\hline Isolated Systolic hypertension & $\geq 140$ & $\geq 90$ \\
\hline
\end{tabular}

Hypertension (HTN), also known as high blood pressure (HBP), is a long term medical condition in which the blood pressure in the arteries is persistently elevated (Naish, Jeannette; Court, Denise Syndercombe 2014). High blood pressure usually does not cause symptoms (CDC, 2015). Long term high blood pressure, however, is a major risk factor for coronary artery disease, stroke, heart failure, peripheral vascular disease, vision loss, and chronic kidney disease (Lackland and Weber, 2015).

High blood pressure is classified as either primary (essential) high blood pressure or secondary high blood pressure (Poulter et al., 2015) About 90 95\% of cases are primary, defined as high blood pressure due to nonspecific lifestyle and genetic factors. Lifestyle factors that increase the risk include excess salt, excess body weight, smoking, and alcohol. The remaining 5-10\% of cases are categorized as secondary high blood pressure, defined as high 36 
blood pressure due to an identifiable cause, such as chronic kidney disease, narrowing of the kidney arteries, an endocrine disorder, or the use of birth control pills (Poulter et al., 2015).

Blood pressure is expressed by two measurements, the systolic and diastolic pressures, which are the maximum and minimum pressures, respectively. Normal blood pressure at rest is within the range of 100-140 millimeters mercury ( $\mathrm{mmHg}$ ) systolic and 60-90 $\mathrm{mmHg}$ diastolic Giuse ppe, (Mancia et al., 2013). High blood pressure is present if the resting blood pressure is persistently at or above $140 / 90 \mathrm{mmHg}$ for most adults (Poulter et al., 2015).

Lifestyle changes and medications can lower blood pressure and decrease the risk of health complications (National Heart, Lung, and Blood Institute, 2015). [Lifestyle changes include weight loss, decreased salt intake, physical exercise, and a healthy diet. If lifestyle changes are not sufficient then blood pressure medications are used (National Heart, Lung, and Blood Institute, 2015). High blood pressure affects between 16 and 37\% of the population globally. In 2010 hypertension was believed to have been a factor in $18 \%$ (9.4 million) deaths.

The World Health Organization has identified hypertension, or high blood pressure, as the leading cause of cardiovascular mortality. The World Hypertension League (WHL), an umbrella organization of 85 national hypertension societies and leagues, recognized that more than $50 \%$ of the hypertensive population worldwide are unaware of their condition. 
Hypertension is a silent killer: Because HTN does not cause symptoms, it is important to have blood pressure checked regularly. HTN cannot be diagnosed unless an elevated blood pressure is found when measured twice at different times (Berman and Synder, 2012).

Diagnosis depends upon accurate and repeated two or more blood pressure readings taken at each two or more visits after an initial screening. The objective of clinical and laboratory evaluation is to establish the presence of HTN. Furthermore, identify other cardiovascular risk factors, diagnose target organ damage, and detect secondary forms of HTN.

There are significant health and economic gains attached to early detection, adequate treatment and good control of HTN. Treating the complications of HTN entails costly interventions such as cardiac bypass surgery, carotid artery surgery and dialysis, draining individual and government budgets (WHO, 2013). Treatment of HTN reduces the risk of stroke, coronary artery disease and congestive heart failure, as well as overall cardiovascular morbidity and mortality from cardiovascular causes. However, only 54 percent of patients with HTN receive treatment and only 28 percent have adequately controlled blood pressure (Takahisa et al., 2013).

Venkata and Ram (2014) pointed out that there is no cure for primary HTN, but blood pressure can almost be lowered or controlled with the correct treatment. The goal of treatment is to lower blood pressure to levels that will prevent heart disease and other complications of HTN. In secondary HTN, the disease that is responsible for the HTN is treated in addition to the HTN itself. Successful treatment of the underlying disorder may cure secondary HTN. 
Treatment to lower blood pressure usually includes changes in diet and getting regular exercise. Patients with mild or moderate HTN who do not have damage to the heart or kidneys may first be treated primarily with lifestyle changes. Lifestyle changes that may reduce blood pressure by about 5-10 mm Hg can be concluded in (reducing salt intake, reducing fat intake, losing weight, getting regular exercise, quitting smoking, reducing alcohol consumption and managing stress).

Lifestyle pattern: Lifestyle pattern is a group of specific forms of how individuals live and interpret their lives in a social context. Lifestyle links the social structure to attitudes and behavior. Therefore, lifestyle is the first line of treatment for H1N, such lifestyle changes include; (dietary habits, physical exercises, alcohol use, smoking, weight, and social stress) this called nonpharmacological therapy (American Society of HTN ASH, 2013).

Lifestyle assessment is the process of identifying behavioral risk factors particular to an individual with the intent to encourage behavior change for the prevention of poor health outcomes in the future. A good assessment will identify what behaviors need to be changed as well as how best to intervene. The most common behaviors of focus in lifestyle assessments are smoking, alcohol use, diet, and physical activity (CDC, 2014).

Lifestyle changes: Lifestyle measures should be instituted, whenever appropriate, and in all patients, subsequently administered. Lifestyle measures are also advisable in subjects with high normal BP and additional risk factors to reduce the risk of developing HTN, (American College of Cardiology (ACC, 2012). 
According to the American College of Cardiology (2012) updated guidelines, lifestyle measures that are widely recognized to lower BP or lead to cardiovascular risks, and that should be stressed and considered are: smoking cessation, weight reduction or weight stabilization, reduction of excessive alcohol intake, physical exercise, reduction of salt intake, increase in fruit and vegetable intake and decrease in saturated and total fat intake.

Hypertension complications in Egypt: In 2013 CDC Egypt pointed out that the rise in blood pressure is the most important risk factor for many types of diseases as affecting heart, arteries, eyes, kidneys, in addition, high blood pressure strain the membranes lining the wall of arteries and leading to a defect in the performance of its functions, as well as it increases stiffness and lack of blood flow as normal. Further, it increases the incidence of stroke to heart or brain and might end up with weakness of heart muscle, damage to the brain or kidney failure. Ischemic heart disease has the first rank in causes of mortality among Egyptians which is estimated as $21 \%$ of all causes of death according to health statistics of the year 2011 .

\section{AIM OF WORK}

To detect the possible effect of some life style factors on blood pressure.

\section{SUBJECTS}

This is a cross sectional community based study.

Subject of this study are selected according to the following inclusion criteria: 
1- Male middle aged (20-40) years to detect the possible life style factors affection on blood pressure and avoid the senility effect of cardiovascular system .

2- Subject should be free from kidney, blood, endocrinal and / or general neurogenic disease.

3- Subject are classified according to blood pressure measurement into:

Group 1- normotensive subject

2- hypertensive subject

(Prehypertension) (Stage 1 hypertension)

Method: Both groups will be subjected to the following investigation:

1- Special questionnaire including:

I- Socio-demographic characteristics of the study subjects

II- Disease information of the study subjects.

III- Life style pattern of the study subjects

2- Clinical examination to detect irregular blood circulation and blood pressure.

3- Cardiovascular performance.

4- Measurement of systolic and diastolic blood pressure.

5- Statistical analysis:

To link between different environmental variable (some life style factors) and level of arterial blood pressure. 
J. Environ. Sci.

Institute of Environmental Studies and Research - Ain Shams University

\section{RESULTS}

The most important results of the study:

Table (1): The correlation between blood pressure and their weight of test group:

\begin{tabular}{|l|c|c|}
\hline \multicolumn{1}{|c|}{ Variables } & Correlation & P-value \\
\hline \hline Checking weight by self & $0.612(* *)$ & 0.000 \\
\hline Patients' knowledge about their ideal body weight & 0.122 & 0.4 \\
\hline $\begin{array}{l}\text { Patients' knowledge regarding effect of body } \\
\text { weight on blood pressure }\end{array}$ & 0.050 & 0.7 \\
\hline BMI categories & $0.810(* *)$ & 0.000 \\
\hline
\end{tabular}

** Correlation is significant at the 0.01 level High significant.

* Correlation is significant at the 0.05 level significant.

Table (2): The correlation between blood pressure and their practicing physical activity of test group:

\begin{tabular}{|l|c|c|}
\hline \multicolumn{1}{|c|}{ Variables } & Correlation & P-value \\
\hline \hline Practicing any type of sports & $0.494(* *)$ & 0.000 \\
\hline Choose the practiced sports & $0.475\left(^{* *}\right)$ & 0.001 \\
\hline Frequencies of practicing sports/ week & $0.469\left(^{* *}\right)$ & 0.001 \\
\hline Frequencies of walking exercises & $0.462\left(^{* *}\right)$ & 0.001 \\
\hline History of being tired during last month & $0.639\left(^{* *}\right)$ & 0.001 \\
\hline Taking any action to avoid body stress & $0.612\left(^{* *}\right)$ & 0.000 \\
\hline Using elevators instead of using the stairs & $0.802\left(^{* *}\right)$ & 0.000 \\
\hline Always use transportation aids instead of walking & $0.764\left(^{* *}\right)$ & 0.001 \\
\hline Sometimes walk for pleasure? & $0.434\left(^{* *}\right)$ & 0.002 \\
\hline $\begin{array}{l}\text { Practice heavy sports for feeling relaxed or being } \\
\text { sweat }\end{array}$ & $0.459(* *)$ & 0.001 \\
\hline
\end{tabular}


Table (3): The correlation between blood pressure and their stress cause symptoms, ways of management and social support of test group:

\begin{tabular}{|l|c|c|}
\hline \multicolumn{1}{|c|}{ Variables } & Correlation & P-value \\
\hline $\begin{array}{l}\text { Using self prescribed medications beside HTN } \\
\text { medications }\end{array}$ & 0.150 & 0.3 \\
\hline Purpose of self prescribed medications about prescribed & $0.764(* *)$ & 0.000 \\
\hline $\begin{array}{l}\text { Asking for knowledge prescribed } \\
\text { medications from physician }\end{array}$ & $0.724(* *)$ & 0.000 \\
\hline $\begin{array}{l}\text { Receiving instructions about current } \\
\text { medications }\end{array}$ & $0.608(* *)$ & 0.000 \\
\hline $\begin{array}{l}\text { Description of feelings \& stress and } \\
\text { adaption }\end{array}$ & $0.748(* *)$ & 0.000 \\
\hline Causes of worries and stress & 0.154 & 0.3 \\
\hline Patients' signs of being stressed & $0.695(* *)$ & 0.000 \\
\hline Patients' satisfaction of current life & $0.667(* *)$ & 0.000 \\
\hline Satisfaction of occupational life & $0.885(* *)$ & 0.000 \\
\hline Presence of social support & $0.877(* *)$ & 0.000 \\
\hline Sources of social support & & \\
\hline
\end{tabular}

** Correlation is significant at the 0.01 level High significant.

* Correlation is significant at the 0.05 level significant.

Table (4): The correlation between blood pressure and their smoking habits of test group:

\begin{tabular}{|c|c|c|}
\hline Variables & Correlation & P-value \\
\hline History of smoking & $0.688(* *)$ & 0.000 \\
\hline Duration of being smoking & $0.707(* *)$ & 0.000 \\
\hline The average number of smoking cigarettes/day & $0.726(* *)$ & 0.000 \\
\hline Quit smoking because of the raised health problem & $0.716(* *)$ & 0.000 \\
\hline
\end{tabular}


Regarding correlation between life style pattern subscales and blood pressure. It was found that there was a significant

I- Positive correlation:

1- Body weight subscale \& blood pressure (table 1).

2- Stress subscale $\&$ blood pressure (tale 3 ).

3- Smoking subscale \& blood pressure (table 4).

II- Significant negative (table 2): correlation between physical activity \& blood pressure.

\section{DISCUSSION}

Although blood pressure is easily measurable it has taken several decades to realize that HTN is a frequent worldwide health disorder. Chronic NonCommunicable diseases are assuming greater importance among adult population in developed as well as developing countries (Kannana and Satyamoorthyb, 2009).

The prevalence of chronic diseases such as HTN, diabetes mellitus etc, is showing an upward trend in most countries. The main factors responsible for this rising trend is changing life styles, obesity, and behavior pattern of people etc. The Joint National Committee reports on prevention, detection, evaluation and treatment of high blood pressure (JNC - VI \& VII) emphasized the necessity of clinicians' appropriate judgment of their patients in diagnosis and treatment. Further, these guidelines for primary care physicians have been specified in the report. Therefore, this national guideline should serve as a tool to be adopted and implemented in local and individual situation (JNC, 2014). 
Approximately $75 \%$ of CVD can be attributed to known risk factors. With changing lifestyles in the Arab countries, there is likely to be greater exposure to risk factors such as high blood pressure, diabetes, physical inactivity, smoking, obesity and diets high in saturated fat, leading to elevated serum cholesterol levels. Increase in proportion of old people is another contributing factor for the high prevalence of CVD. Policies, recommendations and programs designed to control CVD in Arab countries should emphasize what is valuable in traditional diets, existing food supplies, and physical activity patterns.

HTN is a serious health problem not only because of significant mortality and morbidity but also because of its treatment poses complex nursing and medical problems. These problems relate primarily to the difficulty clients experience in complying with long term drug regimens and lifestyle changes that require major behavioral adaptations. Often these behavioral changes are related to cultural patterns and traditions, such as dietary habits, daily activities, and lifestyles. As individuals live longer, there is an increased likelihood that they will develop a chronic disease such as HTN. Because such large numbers of persons are at risk for developing HTN, health professionals must increase, direct their efforts toward prevention and help clients to implement lifestyle changes that will decrease their risk for developing HTN.

Berman and Synder (2012) pointed out that, the goals of lifestyle assessment are to provide the following; 1) an opportunity for clients to assess the impact of their lifestyle on health, and 2) to be a basis for decisions related to desired behavior and lifestyle changes. 
The current study was carried out to detect lifestyle pattern of patients diagnosed with HTN.

Regarding correlation between lifestyle pattern subscales and blood pressure, it was found that there was a significant positive correlation between body weight subscale and HTN, this result was supported by (Nguyen and Lau, 2012), who concluded that, in a meta-analysis study it was reported that, the mean systolic and diastolic blood pressure reductions, is associated with an average weight loss of $5.1 \mathrm{~kg}$.

The study results found that there is a significant negative correlation between physical activity subscale and blood pressure which is supported with all reviewed literature, such as Fagard (2012), a recent meta-analysis of randomized controlled trials concluded that the reduction in resting blood pressure was more pronounced in the hypertensive group $(-6.9 /-4.9 \mathrm{mmHg})$ than in the normotensive one $(-1.9 /-1.6 \mathrm{mmHg})$. Even moderate levels of exercise lowered blood pressure and this type of training also reduced body weight, body fat and waist circumference, and increased insulin sensitivity and HDL-cholesterol levels. Dynamic resistance training decreased resting blood pressure by $3.5 / 3.2 \mathrm{mmHg}$.

Regarding correlation between lifestyle pattern subscales and HTN, it was found that there was a significant positive correlation between stress subscale and blood pressure, this result is supported by Hicken et al. (2013) found that; many reasons may lead to chronic stress that contributes to the well-documented higher prevalence of HTN especially among Blacks than Whites; it is a possible contributor to HTN among Hispanics but not Whites. 
Concerning smoking, the majority of the test group subjects are smokers. From the investigator's point of view, smoking may has a strong effect on the progression of HTN and the increase in hypertensive patients' number. This view is supported by Aikins et al. (2010) who concluded that the relatively higher prevalence of HTN in Africa has been linked to population growth and ageing rising urbanization, mass migration from rural to urban areas, and an increased uptake of western lifestyles including tobacco and alcohol consumption.

The CDC (2013) explained that tobacco injures blood vessel walls and speeds up the process of hardening of the arteries. Tobacco use has a major role in developing HTN among adult male and female. On the same line Shields and Wilkins (2013) mentioned that tobacco use is considered among the first lines leading to HTN and CVD.

Conclusion

The study concluded that following unhealthy life style pattern can lead to HTN, especially regarding total body weight, physical inactivities, stress and smoking.

\section{REFERENCES}

Aikins, A.D., Unwin, N., Agyemang, C., Allotey, P., Campbell, C., and Arhinful D. (2010): Tackling Africa's chronic disease burden: From the local to the global. Globalization and Health 6. doi: 10.118611744-8603-6-SAmerican Society of HTN ASH. (2013). HTN Specialist Annual Scientific Meeting available at: www.ashus.org/.

American Society of Hypertension (HTN): Specialist, Annual Scientific Meeting available at: www.ash-us.org/. 
Berman, Synder, Levett L., Dwyer., Hales., Harvey, Moxham., Park., Parker, R .S and Stanley. (2014): Fundamentals of nursing, 3rd Australian edition, PEARS ON, PP. 598, 599.

Centers for Disease Control and Prevention (CDC). (2015): High Blood Pressure Fact Sheet. CDC. February 19, 2015. Retrieved 6, March 2016.

Centres for Disease Control and Prevention. (2014): National Centre for Health statistics. Health Data Interactive. Centres for Disease Control and Prevention Web site. Heart Disease and Stroke Statistics. Update A Report From the American Heart Association http://www.cdc.gov/nchs/hdi.htm.

Giuseppe, Mancia; Fagard, R; Narkiewicz, K; Redon, J; Zanchetti, A; Bohm, M; Christiaens, T; Cifkova, R; De Backer, G; Dominiczak, A; Galderisi, M; Grobbee, DE; Jaarsma, T; Kirchhof, P; Kjeldsen, SE; Laurent, S; Manolis, AJ; Nilsson, PM; Ruilope, LM; Schmieder, RE; Sirnes, PA; Sleight, P; Viigimaa, M; Waeber, B; Zannad, F; Redon, J; Dominiczak, A; Narkiewicz, K; and Nilsson, PM. (2013): 2013 ESH/ESC Guidelines for the management of arterial hypertension: The Task Force for the management of arterial hypertension of the European Society of Hypertension (ESH) and of the European Society of Cardiology (ESC). European Heart Journal. 34 (28): 2159-219.

Hicken MT, Lee H, Morenoff J, House JS, and Williams DR. (2014): Racial/Ethnic Disparities in Hypertension Prevalence. Am J Public Health , 104 (1), 117-23.

Hicken, M.T; Lee, H; Morenoff, J; House, J.S and Williams, D.R. (2014) Racial/Ethnic Disparities in HTN Prevalence: Reconsidering the Role of Chronic Stress. American Journal of Public Health. 104 (1): $117-123$

Kannana, T.S., Stayamoorthy B \& Ramachandra, S. (2009): An Epidemiological Study Of Hypertension In A Rural Household Community, Journal Of Medicine, 11 (2). 
Lackland, DT; and Weber, MA; (2015): Global burden of cardiovascular disease and stroke: hypertension at the core. The Canadian journal of cardiology. 31 (5): 569-71.

Naish, Jeannette; Court, Denise Syndercombe. (2014): Medical Sciences (2nd ed.). Elsevier Health Sciences; Imprint: Saunders Ltd. p. 562.

National Heart, Lung, and Blood Institute (NHLBI). (2015): How Is High Blood Pressure Treated?". Retrieved 6 March 2016.

Nguyen T1, Lau DC. (2012): The Obesity Epidemic and Its Impact on HTN. Can J Cardiol. 28(3):326-33.

Paul A. James, Suzanne Oparil, Barry L. Carter, Pharm D. (2014): EvidenceBased Guideline forth Management of HTN. JAMA.; 311(5):507520

Poulter, NR; Prabhakaran, D; and Caulfield, M. (2015): Hypertension. Lancet (London, England). 386 (9995):801-12.

Takahisa Sawada, Hiroyuki Yamada, Bjo“rn Dahlo. (2009): Retraction of: Effects of valsartan on morbidity and mortality in uncontrolled hypertensive patients with high cardiovascular risks: KYOTO HEART Study. Eur Heart J; 30:2461-2469. 


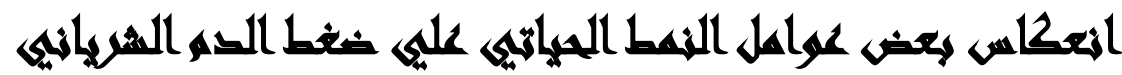

\section{[r]}

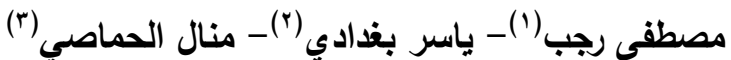

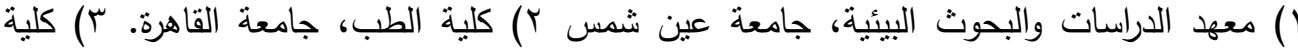

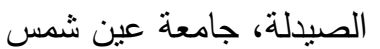

\section{(المستخلص}

فرط ضغط الدم (Hypertension) حالة مرضية نتصف بارتفاع ضغط الدم الثريانى بصورة

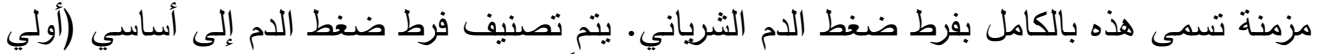

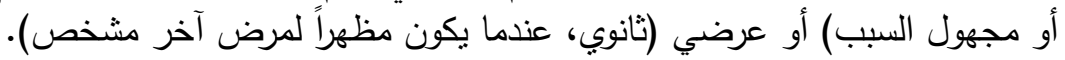

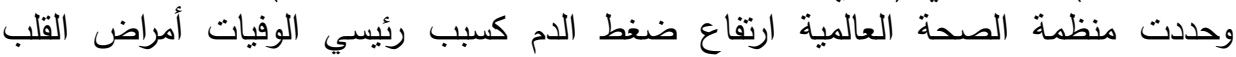

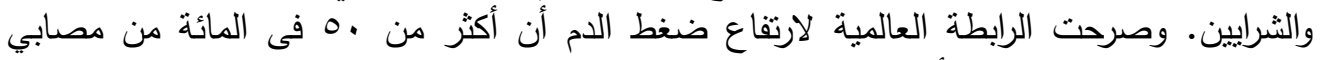

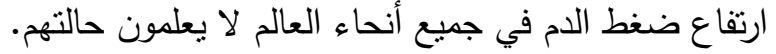

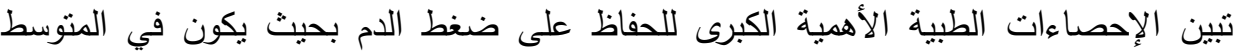

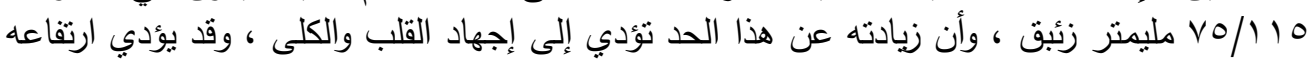

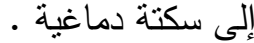
يمكن لارتفاع ضغط الام على مدى فترة من الزمن أن تساهم فى كثير من الأمراض، بما فى ذلك: فتنل القلب.

السكتة الدماغية.

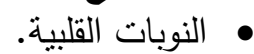
مرض نمط الحياة: مرض مرنبط بطريقة حياة الناس. أمراض نمط الحياة تشئة التمل تصلب الشرايين

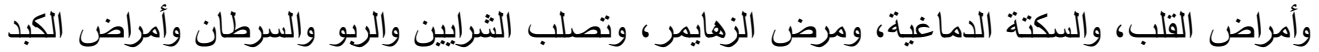

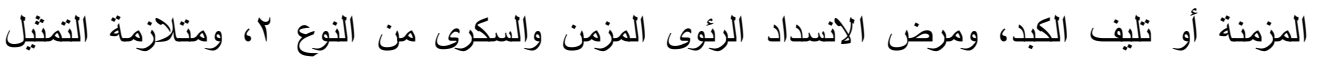

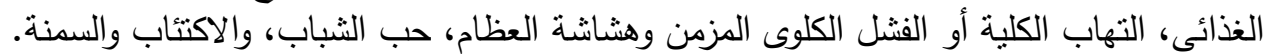
أمراض نمط الحياة هى نتيجة الطريقة التى نقود بها حياتتا. تتم تسمية هذه أيضاً أمراض طول

$$
\text { العمر أو أمراض الحضارة. نمط الحياة هي }
$$

أمراض نمط الحياة هى نتيجة وجود علاقة سيئة من الناس مع بيئتهم.

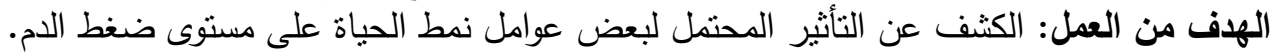

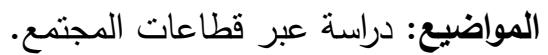
يتم اختيار موضوع هذه الدراسة وفئة وفقاً للمعايير التالية:

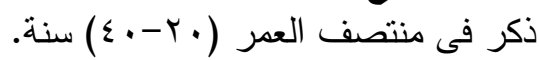
يجب مراعاة أن يكون خالى من أمراض الدم، والكلى، والغدد الصماء. 


$$
\begin{aligned}
& \text { يتم التصنيف وفقاً لقياس ضغط الدم إلى: }
\end{aligned}
$$

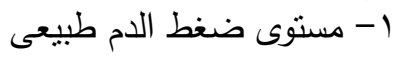

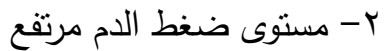

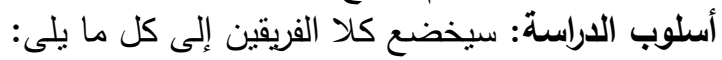

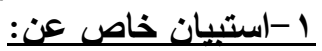

$$
\begin{aligned}
& \text { 1- خصائص المريض الاجتماعية (العمر - السن - الحالة الاجتماعية) }
\end{aligned}
$$

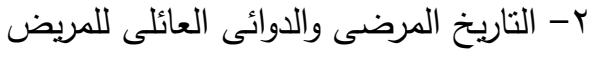

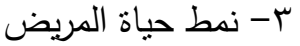

$$
\begin{aligned}
& \text { r - الفحص السريرى للكثف عن عدم انتظام الدورة الدموية وضغط الدم: }
\end{aligned}
$$

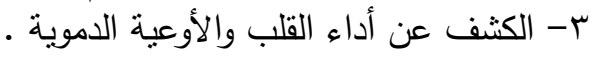

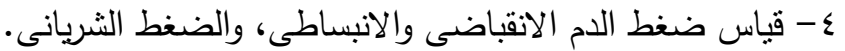

$$
\begin{aligned}
& \text { (السمنة)، التوتر النفس، التدخين). }
\end{aligned}
$$

0- التحليل الإحصائى: وذللك للربط بين المتغيرات البيئية المختلفة (بعض عضئين عوامل نمط الحياة)

النتائج وملخص المناقثة: رصد علاقة إيجابية بين مستوى ضغط الدم، (ومؤشر كتلة الجسم

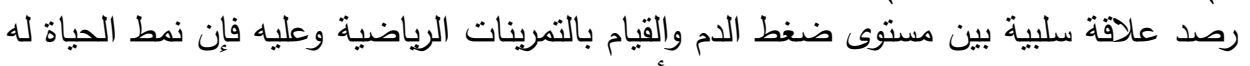

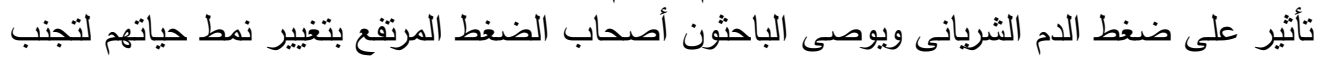

يساعد تغيير نمط الحياة بشكل فعال في خفض ضغ ضغط الدام بدرجة تعادل قدرة الأدوية الفردية

الخافضة للضغط. 